\title{
National Interest and European Law in the Legislation and Juridical Practice on Health Care Services - In the Light of the Reforms of the Hungarian Health Care System ${ }^{1}$
}

\author{
István Hoffman \\ Eötvös Loránd University, Faculty of Law, Department of Public Administration, \\ Hungary \\ hoffman.istvan@ajk.elte.hu
}

\section{ABSTRACT}

The priority of the national interest in the field of the health care policy is secured by the rules of the TFEU, the Charter of Fundamental Rights of the European Union and by the secondary law as well. Although several market-type and pro-competitive solutions have appeared, they can have only limited influence on the national systems. The main reasons of the limited influence of the EU regulations are the primary responsibilities of the Member States, the widely applicable public health exceptions, and the limited application of the EU competition rules. Although the national legislation is the determinative, the EU regulations on the free movement of persons and services could be applied in the field of the health care services. This principle was recognized by the landmark decisions of the Court of Justice (ECJ). The Directive 2011/24/EU is based on these principles and a limited competition has evolved. Because the competition is limited and the creation of a single European health care area has just begun, the "silent revolution" of the public service provision has a minor importance. The practice of the ECJ has been focused on the use of the cross-border services and the Member States have had a broad margin for the organisation and management of this public service. The role of the European legislation on the competition is limited in this field as well. Therefore the strong centralization of the Hungarian health system from 2011 to 2013 may be in harmony with the EU legislation, although the competition at the national level is not promoted by the reformed Hungarian rules on health care.

Keywords: health care, harmonization, impact of the EU on national health policies, national health policies, Hungary

1 This study is based on investigations of the Research Group of the Hungarian Academy of Science and the University of Debrecen (MTA-DE) on Regulations of Local Public Services (2012-2016).

Hoffman, I. (2015). National Interest and European Law in the Legislation and Juridical Practice on Health Care Services - In the Light of the Reforms of the Hungarian Health Care System. International Public Administration Review, 13(1), 135-158. 


\section{Introduction}

The significance of the health care services has been increasing during the last decades in the modern European countries. This growing importance has several demographical, social and economic reasons.

The social care, the health care and the social benefits, the social partnership and dialogue and several rules on the world of the labour belong to the European social policy (Clasen, 2007, pp. 603-604). The rules on the health care services are part of it as well.

The article 151 of the Treaty on the Functioning of the European Union (hereinafter TFEU) states that the social policy belongs primarily to the responsibilities of the Member States. The article 168 of the TFEU has a similar regulation: in the field of Public Health the main responsibilities of the Member States are highlighted by the Article 168 of the TFEU: the Union action shall complement the national policies in this field (Clasen, 2007, p. 612).

The health care is considered as services by the guideline decisions ${ }^{2}$ of the European Court of Justice, therefore the legislation and juridical practice on the free movement of services has an important role in the field of health care. If we would like to examine the role of the national interest in the field of the health care it is important to note that these services can be interpreted as services of general interest after the article 14 of TFEU. The "essential role and the wide discretion of the national, regional and the local authorities" is confirmed by the Protocol No. 26 (of the TFEU) on Services of General Interest. The approach of these policies defined by the TFEU is consistent with the rules of the Protocol No. 26 (de Vries, 2011, p. 312). If the health care involves the movement of goods as well then the rules of TFEU on the free movement of the goods shall be applied. ${ }^{3}$ The free movement of labour is promoted by the free access to health services (Nistor, 2011, pp. 36-38). ${ }^{4}$

Although the main responsibilities of the Member States are recognised by the TFEU, several Union competencies are secured by the regulations on the "four freedoms". These competencies are strongly limited by restrictions justified on grounds of the protection of health and human life thus practically the national interest in public health can be a justified ground of the restrictions of these freedoms. This regulation also suggests that the competition law of the EU shall be applied in the field of health care (de Vries, 2011, p. 295) but there are special circumstances.

2 See for example the case C-159/90 The Society for the Unborn Children Ltd. vs. Stephen Grogan and others, [1991], ECR I-4685.

3 See for example the case C-120/95 Decker vs. Caisse de maladie des employés privés [1998] ECR I-1831.

4 See for example the case C-158/96 Raymond Kohll vs. Union des caisses maladie [1998] ECR I-1931. 
The health care services are strongly influenced by the national interest, however the European Union has significant responsibilities. Therefore I would like to examine the role of the national interest in an inside-out manner, to investigate the role of the European integration, practically limiting the national interest.

To examine the limits of the national interest the review of several national policies is required. This review is limited to the changes of the Hungarian health care and the interaction of the Hungarian national legislation based on the national interest and the European legislation as well. Hungary is a good example, because different stages and approaches can be reviewed. Our analysis is based on the review of the European and Hungarian legislation and juridical practice. The analysis of the funding and the economic impacts of the legislation are just additional. Therefore the EU legislation and juridical practice will be reviewed and the impact of the different fields of the EU rules and acquis on the Hungarian legislation will be analysed by this article. The significance of the cross-border health service will be presented by statistical surveys on the funding and literature reports and analysis on this topic.

\section{The Impact of the Public Health and Social Legislation of the European Union on the National Policies on Health Care}

The priority of the national interest is shown by the late institutionalisation of the public health policy of the European integration (Clasen, 2011, pp. 410-411; Fazekas \& Koncz, 2013, p. 31). As mentioned above the main responsibilities of the Member States of the European Union remain unchanged. Although the national policies have the greatest importance, these European policies have been evolving and the EU legislation has been changing in the last decades, as well.

\subsection{Frameworks of the Fundamental Rights}

In the last decades - in addition to the evolving social dimension - the fundamental rights approach of the formerly economic integration has emerged. This approach appeared primarily in the case law of the European Court of Justice (Kaczorowska, 2013, p. 217-218). Several rules on the founding treaties of the European integration were applied with a fundamental law approach by the ECJ. The ECJ took into account the rules of the European Convention on Human Rights mainly when the founding treaties were interpreted. The fundamental rights legislation of the EU was based on this practice of the ECJ (Craig \& de Burca, 2003, p. 69).

The health care services are regulated by several rules of the Charter of Fundamental Rights of the European Union, which has the same legal value as the European Union treaties following the entry into force of the Lisbon Treaty in 2009. 
The fundamental rights approach has a direct influence on the national health care systems. Although the national interest is recognised by the article 35 of the Charter, this rule states that everyone has the right to access the preventive health care and the right to benefit from medical treatment (Waltermann, 2001, pp. 49-50). The principles of the access to services are not regulated by the Charter, thus the different national health care systems can be prevailed. Therefore the importance of the health care systems within the welfare systems is different, the significance of which can be compared by the share of the health care expenditures. This is shown by the following table.

Table 1: The share of health care spending within the welfare expenditures in the Member States of the European Union from 2000 to 2011 (in \%)

\begin{tabular}{|c|c|c|c|c|}
\hline $\begin{array}{l}\text { Countries or group of } \\
\text { countries }\end{array}$ & 2000 & 2005 & 2009 & 2011 \\
\hline EU-27 & - & 28,92 & 29,49 & 29,39 \\
\hline $\begin{array}{l}\text { Euro zone } \\
\text { (EU-17, except Latvia) }\end{array}$ & 28,34 & 28,99 & 29,73 & 29,59 \\
\hline Belgium & 27,61 & 28,74 & 28,45 & 28,78 \\
\hline Bulgaria & - & 29,03 & 24,19 & 25,99 \\
\hline Czech Republic & 33,63 & 35,26 & 32,33 & 31,92 \\
\hline Denmark & 20,19 & 20,72 & 21,94 & 20,97 \\
\hline Germany & 29,68 & 28,78 & 32,33 & 33,28 \\
\hline Estonia & 32,10 & 31,94 & 28,36 & 27,96 \\
\hline Ireland & 39,36 & 39,20 & 39,03 & 45,04 \\
\hline Greece & 25,84 & 27,79 & 29,13 & 25,86 \\
\hline Spain & 29,86 & 31,37 & 29,28 & 27,38 \\
\hline France & 28,75 & 29,85 & 28,88 & 28,52 \\
\hline Italy & 24,40 & 26,66 & 26,62 & 24,86 \\
\hline Cyprus & 27,46 & 25,25 & 24,39 & 22,69 \\
\hline Latvia & 17,66 & 27,47 & 23,49 & 21,29 \\
\hline Lithuania & 29,81 & 30,17 & 26,54 & 27,75 \\
\hline Luxembourg & 25,42 & 25,66 & 25,42 & 25,42 \\
\hline Hungary & 27,90 & 29,89 & 23,81 & 27,76 \\
\hline Malta & 29,31 & 29,34 & 30,93 & 29,33 \\
\hline Netherlands & 29,34 & 30,67 & 35,05 & 35,68 \\
\hline Austria & 25,88 & 25,67 & 25,80 & 25,23 \\
\hline Poland & 19,64 & 19,80 & 25,08 & 23,13 \\
\hline Portugal & 32,01 & 30,15 & 28,65 & 25,05 \\
\hline Romania & 25,93 & 28,42 & 24,53 & 25,13 \\
\hline Slovenia & 30,65 & 32,35 & 32,90 & 31,57 \\
\hline Slovakia & 34,85 & 29,90 & 31,51 & 30,49 \\
\hline Finland & 23,77 & 25,86 & 25,59 & 25,53 \\
\hline Sweden & 26,78 & 25,94 & 25,28 & 25,70 \\
\hline United Kingdom & 25,51 & 30,87 & 31,30 & 31,51 \\
\hline
\end{tabular}

Source: Eurostat, 2013. (Retrieved 25th April 2014 from

http://epp.eurostat.ec.europa.eu/tgm/table.do?tab=table\&init=1\&language=en \&pcode=tps00106\&plugin=1) 
National Interest and European Law in the Legislation and Juridical Practice on Health Care Services - In the Light of the Reforms of the Hungarian Health Care System

After the article 35 of the Charter a high level of human health protection shall be ensured in the definition and implementation of all Union policies and activities, which is an objective of the EU and not a subjective right.

\subsection{Regulation of the EU Primary Law}

\subsubsection{Rules on Public Health}

The primacy of national responsibilities on the health care legislation is indicated by the above mentioned regulation of the Charter of Fundamental Rights of the European Union. This approach appears in the TFEU as well. The point $k$ ) paragraph 2 article 4 of the TFEU states, that the "common safety concerns in public health matters, for aspects defined in this Treaty" belong to the shared competences between the Union and the Member States. These shared competences are mirrored by the article 6 of the TFEU: in the field of the "protection and improvement of human health" the EU has competence to "carry out actions to support, coordinate or supplement the actions of the Member States". Thus the main activity of the Union is the Open Method of Coordination (OMC) of the health care activities of the Member States (Clasen, 2011, p. 411).

Important regulations by which the health care services are affected are regulated by the Title XIV of the TFEU on the public health (which is based on the approach of the article 35 of the Charter of Fundamental Rights). The paragraph 7 article 168 states, that the "Union action shall respect the responsibilities of the Member States for the definition of their health policy and for the organisation and delivery of health services and medical care." The primacy of the national responsibilities is highlighted by the article 153 of the TFEU on the field of the European social policy as well. And article 168 of the TFEU states that Union actions shall be directed towards improving public health, preventing physical and mental illness and diseases, and obviating sources of danger to physical and mental health. These actions include the promotion of research into the causes, the transmission and prevention of physical and mental illness and diseases, the health information and education, the monitoring and early warning of them and combating serious border-cross threats to health. The complementary responsibilities of the EU in the field of the drug policies of the Member States is regulated by Public Health Chapter if the TFEU as well.

In summary, the Member States have obviously primary responsibilities, thus the national interest dominates the public health policy. The main and most important responsibility of the European Union is the coordination of national policies. The Open Method of Coordination does not include direct, legally enforceable interventions, but the convergence of the different and various health care systems and the increased efficiency of these systems can be helped by the exchange of good practices, by mutual learning. This OMC can be observed in several areas of the health care and not only the changes of 
the funding of health care (mainly the changes of the social insurance systems), however the service delivery system and the health care organization and management and the regional health services are impacted by it. Thus this (legally) soft tool can be a catalyst of the convergence in the EU, and might have greater influence on the national policies and legislation than the topdown legal harmonisation (Koivusalo, 2013, pp. 100-101; Hervey \& McHale, 2004, pp. 412-413).

\subsubsection{Provisions of the Treaties on Social Policy}

Title $X$ of the TFEU on the social policy has a significant impact on the health care services organised at the national level even if the priority of the national responsibility prevails. The role of the national interest in the field of the social policy can be the topic of a separate publication therefore I would like to remark only several facts. The coordination of the national social security systems and policies has a great impact on the national interest because this soft tool resulted in several convergence phenomena in the field of the access to the health care services and benefits. The European Social Fund (ESF) is regulated by the Title XI of the TFEU, thus it is defined practically as a part of the European social policy in a broad sense. The actions of this Fund have a great impact on the health policies of the new, Eastern Central and Baltic EU Member States, because those countries are the recipients of the majority of the grants of the ESF (Koivusalo, 2013, pp. 113-115).

\subsection{Provisions of the Secondary Law}

The national legislation and the national interest are mainly indirectly impacted by the regulations based on the rules of the Title X, XI and XIV. The intergovernmental public health relations are impacted by the regulations based on the public health rules of the TFEU (Fazekas \& Koncz, 2013, p. 31). The norms of the secondary law which impact the national systems and the national interest significantly are the rules on the Four Freedoms and the EU competition law.

\subsubsection{The Impact of the Four Freedoms on the National Interest in the Field of the Health Care}

The health care can be considered as a service as well, therefore - having regard to the shared competences of the Union and the Member States in the field of health care - the EU rules on freedom to provide services can be applied at least partially (the limits of the application of these rules will be reviewed later). These norms and decisions of the ECJ impacted the health care because the framework of the cross-border health services emerged from them.

The access to the welfare services (including the health care) is one of the most important preconditions of the free movement of persons. Therefore 
the access to the health care is strongly impacted by the provisions on the coordination of social security services. The health care is a kind of personal care which is based on the personal activities of the employees organised by the providers authorized by the law. Therefore the national policies are impacted by the EU labour law rules (for example the directives on the fixed-term employment and on the working hours). Last but not least the mutual recognition of medical classification has a strong impact on the free movement of medical employees within the EU.

The national health care policies are impacted by the rules on the free movement of goods. The production, commerce and official monitoring of the pharmaceuticals and medical devices have been changed by the EU legislation.

The national health care services are influenced by the EU competition law, the law on the state aid and the regional development policy as well.

Although competencies of the EU are ensured by these rules, the enforcement of the national interest is widely provided by the public health clause which allows the limitations of the four freedoms (Koivusalo, 2013, p. 98; Hervey \& McHale, 2004, p. 70).

\subsubsection{Health Care as a Special Service - The Impact of the Freedom to Provide Services on the National Interest in the Field of the Health Care}

The "services" are defined by the article 57 of TFEU, the services are normally provided for remuneration in so far as they are not governed by the provisions relating to freedom of movements for goods, capital and persons. The health care is basically provided for remuneration - generally funded or supported by the mainly public health insurance agencies, the health insurance companies, governed by the public law or by the central government - and the personal care (excluding the medication and the medical device supply) is not governed by the provisions relating to freedom of movements for goods, capital and persons (Fazekas \& Koncz, 2013, p. 52-54) therefore the application of the provisions relating freedom to provide services has been incurred.

The finance of the health care service has been impacted significantly by the "Insurance Directives". Market-based private insurance was authorised by First Non-Life Insurance Directive (Directive 73/239/EEC) thus the private sector has had the opportunity to provide additional or replacement health services (Gronden, 2011, p. 135). A "single license system" was introduced by the "Third Non-Life Insurance Directive" (Directive 92/49/EEC) and this European legislative act allows individuals and business to buy insurance in another Member States. Thus the insurance market - and the market of the health insurance - was liberalized and the competition was strengthened by the Directives. The main impact of this Directive was the increasing competition within the different national markets (den Exeter, 2002, 
p. 274-275). Although the competition was encouraged, the article 54 of the "Third Non-Life Insurance Directive" defined a strong "public interest" exception. Therefore the general rules on competition may be just limitedly applicable.

One of the first major decisions of the ECJ which allowed the application of the provisions relating to freedom to provide services was the case Luisi \& Carbone. ${ }^{5}$ The ECJ states in the Luisi \& Carbone that if somebody travels to another country for taking health care then this activity can be considered as service. Therefore this right (for travelling) cannot be limited. The impact of this case was just indirect because the main point of it was not the major area of the health care (Nistor, 2011, p. 36).

The Grogan case cited above was the first one in which the ECJ stated that the health care (in the given case the health care services relating to the abortion) can be considered as services because of the direct economic relation between the provider and the recipient. In this case the ECJ recognised that the private health care is practically a type of service (Hervey, 2011, p. 221). After the Grogan case it was an open question whether the health care funded by social insurance belongs to the services or not. The service nature of the health care services and benefits funded by the social insurance agencies was recognized by the Kohll case cited above. However the ECJ highlighted in the Kohll casebased on the decision of the Webb case $e^{6}$ that several special phenomena of the services funded by social insurance do not allow automatic access to the cross-border services. Nevertheless, the social security agency of Luxembourg was condemned for violation of the free movement of services because the agency did not want to reimburse the cost of orthodontic treatment of the minor daughter of the Luxembourgian Raymond Kohll which was provided in Germany (Bekkedal, 2011, p. 65). The cross-border access to welfare services was recognised by this decision, but the ECJ took into account the primality of the national responsibilities in the field of health care services as well. Thus the prior authorisation of the service was not constituted basically unlawful. ${ }^{7}$

Thus the health care was considered as service by the European Court of Justice but the priority of the national policies and responsibilities have been taken into account relating to the lawful limitations of the free movement of services. The transforming juridical practice was the base of the secondary legislation of the cross-border health services (Fazekas \& Koncz, 2013, pp. 51-52).

The new approach of the legislation was embodied by the Directive 2011/24/ EU of the European Parliament and of the Council of 9 March 2011 on the application of patients' rights in cross-border healthcare. By this directive the healthcare is considered as service unambiguously and the national legislations

5 Joined cases C-286/82 and C-26/83 Luisi and Carbone [1984] ECR 377.

6 C-297/80 Webb[1981] ECR 3305.

7 See case Geraets Smits, C-157/99 B.S.M. Geraets-Smits vs. Stichting Zickenfonds [2001] ECR I-5473. 
on the cross-border health care were harmonized by this norm which is practically a paradigm shift after the coordinative approach basing on the rules on European social policy, the rules on the coordination of the national social security systems and the rules on the coordination of the national public health policies (Peeters, 2012, p. 29). The new directive is based on the free movement of the persons (Fazekas \& Koncz, 2013, p. 51). Although the cross-border healthcare was a reality before the publication of this directive, after the leading cases of the ECJ the funding of these services are welldefined by this rule. Thus the national funding authority of the patient should reimburse the costs of the services. The maximum rate of the reimbursement is the publicly financed costs of healthcare provided by healthcare providers established on its own territory of the recipient but if this maximum is higher than the costs of the cross-border providers than the - cheaper - foreign costs shall be reimbursed. The expenses shall be anticipated by the patient and the reimbursement will be received by the patient. In accordance with the decision of the Geraets-Smits decision, the Member States are permitted to restrict the freedom to provide medical and hospital services in so far as the maintenance of treatment capacity or medical competence on national territory is essential for public health. Therefore the directive states that the prior permission of the national funding authority of the patient is required for the in-patient care services and for the special and expensive care (Fazekas \& Koncz, 2013, pp. 52-53).

Thus the possibility of the cross-border health care was extended by the directive. Therefore the competition between health care providers has increased which can improve the quality of the services. On the other hand the unifying "health care market" can help the compensation of the allocation of capacities thus the waiting lists may be decreased because the economy of scale of the system is promoted. Thus services can be provided to patients in the countries where these lists are shorter (Lamping, 2013, p. 23-24).

The relationship of trust in health care, the linguistic differences and the lack of information about the cross-border healthcare services and the complicated national regulation on the finance, accounting and reimbursement of these benefits are strong limitations of the cross-border healthcare. Thus the "single European healthcare market" is rather a wish than a reality (Meyer, 2013, p. 102); the number of cross-border patients is relatively low. The directive had a relatively significant impact on the providers close to borders. The impact is more significant if the linguistic differences between the countries are not remarkable (identical or very similar language is spoken in the given countries). Thus (a partial) opening of the health care markets have been evolved in several border regions (Legido-Quigley et al., 2008, pp. 48-51).

\subsubsection{Free Movement of Persons}

The roots of the EU law on health care are related to the rules on the free movement of persons. The coordination of the social security systems 
is based on the free movement of labour and by the dismantling the barriers to labour migration. One of the major barriers was the social insurance status of the migrant workers (Carter, 2002, pp. 187-188) which included the health insurance status of these persons as well. Firstly the regulation 1408/71/EEC addressed these questions and now the rules on the coordination of social security system are found in the regulation 883/2004/EC. The philosophy of these regulations was the equal status of migrant workers to resident workers with regard to the benefits of the social security systems.

Therefore the cross-border (non-residential use of) social - including health care services - is permitted in two cases by the Regulation 883/2004/EC. Firstly the article 19 of the Regulation covers the situation where an insured person and the members of his family are staying in a Member State other than the competent Member State (Nistor, 2011, p. 336). These persons shall be entitled to the benefits in kind which become necessary on medical grounds during their stay, taking into account the nature of the benefits and the expected length of the stay. Secondly, the additional services which are approved in advance by the health insurance body of the given person (by an $\mathrm{E} 112$ or S2 form). The equal status of the patients is secured by the regulation therefore the total cost of the care (except the mandatory deductibles which should be paid because payment obligation is defined by the legislation country of the service provision) is reimbursed by the national insurer of the provided person. The reimbursement is received by the health insurer of the country of the service provision and the cost of the care will be paid to the provider by the insurer. The occasional care influences the health systems only slightly as it is an emergency or emergency like care. ${ }^{8}$

The national health systems could be more significantly impacted by the care which is approved in advance (and are based on the form E112 or S2), because the costs of this service are fully reimbursed by the national insurer of the patient. But the permission process and the principle of the total reimbursement - thus the national insurer shall reimburse the total costs of the given service even if it is much higher than the similar service provision in the home country - caused a limited impact on the national interest. These tools are used when a rare disease shall be healed or a complicated treatment is needed. Therefore this tool is in harmony with the national interest: those patients can receive the service which cannot be sufficiently cared by the national provider. This legal instrument impacts on a narrow segment of the national health systems.

The national health systems and the national interest in health policies are impacted by the rules on the mutual recognition of medical qualifications which are based on the rules on public health of TFEU. The public health exception prevails in this field as well. Although the main aim of these norms

8 This regulation has a more important impact on the travel insurance market in the EU because the private health insurance as part of the travel insurance packages lost their significance partially (Greber et al., 2001, p. 245). 
National Interest and European Law in the Legislation and Juridical Practice on Health Care Services - In the Light of the Reforms of the Hungarian Health Care System

to secure the free movement of the employees who hold medical degrees the national legislations have the possibility to define several special norms to secure the proper level of training of the medical employees (Hervey \& McHale, 2004, pp. 418-420).

\subsubsection{Free Movement of Goods}

The national interest in health care is impacted by the free movement of goods however not so significantly. The article 28 of TFEU states that the EU is a customs union (Fabio, 2010, p. 11-12). Therefore the distribution and trade of medical devices, medicaments (drugs) are included within the free movement of goods as well. A strong limit of this freedom is the public health exception which will be reviewed in the section 2.4.

The ECJ stated that this freedom should be applied in the trade of medical devices and drugs as well. This regulation impacted the funding of the services because several restrictive and protective national financial and reimbursement regulation were considered as provision having equivalent effect with customs and quantitative restrictions (Waltermann, 2011, pp. 44-45). Thus the ECJ stated in the case Decker that the Luxembourgian social law violated the regulation on the free movement of goods because the price of the glasses bought in Belgium was not reimbursed by the social insurance agency of Luxemburg. ' Similarly the absolute ban of the mail-order services could violate - in certain circumstances - the principle of free movement of the goods as well. ${ }^{10}$

Thus the trade of the medicaments has been impacted by the European rules on the free movement of goods. These regulations and the system of European reference pricing of pharmaceuticals resulted in a unifying European pharmaceutical market and a stronger competition has evolved (Dawson, 2011, pp. 171-712).

\subsubsection{The Public Health Exception}

The legislation of the European Union could be characterised as a "marketfriendly" one from the 1980s and 90 s in the field of the health care. The national interest which primarily has been embodied in the public health exception was a strong limit of the pro-market approach.

As mentioned above, the ECJ stated that the EU regulation on the free movement of the goods and services could be infringed by the general and unconditional bans. Those bans which are not general and have specific conditions could be in harmony with the EU law because of the restrictions which could be permitted by the public health exception. The prohibitions have been reviewed by the ECJ and those prohibitions can be permitted

9 L. C-120/95 Nicolas Decker vs. Caisses de Maladie de Employés Privées [1998] ECR-I 1831.

10 See C-322/01 Deutscher Apothekerverband eV vs. 0800 DocMorris NV \& Jacques Waterval [2003] ECR I-14887. 
which could be effective. If the Member States could not prove that the given prohibition was necessary and it could substantially improve the public health of the given country, then the ban was classified as an infringing one (Moens \& Trone, 2010, pp. 52-53). ${ }^{11}$

This necessity and proportionality test based on the public health clause allowed the legitimate restrictions of the enforcement of the four freedoms. Thus the ECJ stated that the mandatory retirement of doctors above a defined age is not contrary to the discrimination ban because these rules could improve the national public health (Сraig \& de Búrca, 2011, p. 900). ${ }^{12}$

Thus the national interest has been a strong limit of the Europeanization of the rules on health care. Therefore the "silent shift of the regulation on public services" - by which the solutions governed by the public law have been preferred (Horváth M., 2013, p. 180) - has less influence on the provision of the health care services because the EU law allowed just a partial service delivery opening. The reformation of the market structure has not been necessary because the market structures have only partially evolved.

\subsection{Application of EU Competition Law}

The rules on competition had the least influence on the health services. The application of the market or market type solutions were contributed by the classification of the funding agencies as undertakings. If the funding agencies - practically the social insurance agencies or the funding agencies of the central governments - were undertakings, then the EU regimes on competition, on public procurement and on state aid would be applied.

The ECJ is being consistent that the health insurance (social insurance) bodies are not to be considered as undertakings. The ECJ stated firstly in the Poucet and Pistre joined cases that the social insurance agencies are not undertakings. ${ }^{13}$ The ECJ highlighted in the AOK Bundesverband case that the federations of these social insurance bodies are not undertakings. ${ }^{14}$ In the INAIL case the ECJ stated that it does not infringe the EU competition law if just one accident insurance body is established in a country. ${ }^{15}$

The application of the public health clause resulted in the evolvement of a special regime in the field of the health care public procurement which allowed

11 Thus the ECJ stated in the case C-170/04 Rosengren and Others vs. Riksåklagaren [2007] ECR I-4071 that the restrictive regulations on the alcohol import of the Swedish citizens is not in harmony with the EU rules on the free movement of goods because the structure and level of the Swedish alcohol consumption is not substantially influenced by these national provisions.

12 See the case C-341/08 Domnica Petersen vs. Berufungsausschuss für Zahnärzte für den Bezirk Westfalen-Lippe [2010] ECR I-47 in which the ECJ stated that it is in harmony with the defence of the (national) public health that the German dentists should retire when they reach the age of 68 .

13 See more the joined cases C-159/91 and C-160/91 Poucet and Pistre [1993] ECR I-637.

14 See more the case C-264/01 [2004] ECR I-2493.

15 See more the case C-218/00 Cisal di Battistello Venanzio \& C. Sas vs. INAIL - Istituto Nazionale per l'assicurazione contro gli Infortuni sul Lavoro [2002] ECR I-691. 
National Interest and European Law in the Legislation and Juridical Practice on Health Care Services - In the Light of the Reforms of the Hungarian Health Care System

just a restricted and controlled (national) market opening (Waltermann, 2009, p. 45; Hatzoupolous \& Stergiou 2011, pp. 416-419).

\section{The Transformation of the System in Hungary: Clear and Strong Enforcement of the National Interest - A Legal Analysis}

As mentioned above broad national legislative and regulatory competences are allowed by the EU law. The coordination of the national social security systems and the cross-border health care services are regulated by the Union. The definition of the main elements of the health systems - for example the funding of health care, the structure and ownership of the providers, the legal status and number of the insurers - belong to the national competences. This framework provides a broad scope for the national regulation.

\subsection{The Changes of the Approaches of the Hungarian Legislation on Health Care - Until 2011/13}

From 1975 the health care system of the Hungarian socialist (communist) state was a universal one. This system was modified after the Change of the System. From 1992/93 a Bismarckian model was followed which was managed by corporate authorities (corporate self-governments).

The Hungarian system has had significant funding difficulties therefore the main aim of the reforms since the 1990s has been the cost reduction. In these reforms several elements of the New Public Managements and the Good Governance were used (Hoffman, 2013, p. 640). Thus several pro-market solutions and market-type mechanisms were applied as well.

\subsection{Recent Legislative Reforms on Health Care - And the Impact of the Reforms}

\subsubsection{A Centralised Health Care System}

The former approach was radically changed by the change of government in 2010 when new, state-centred and public law governed service management trends had evolved. In the last two decades the health system was based on the - mainly limited - competition of the providers, the distribution of the powers and duties between the central and the local government - in which model the central government was primarily responsible for the regulation, for the funding and for the inspection of the system and for the maintenance of several central institutes (for example the university clinics) and the local governments were responsible for the maintenance of the providers and for ensuring the access to the health care. The new model is a centralized system. Because the inspection of the providers and the funding was centralized in the former system the service delivery was strongly impacted by the reforms. 
The first step of the transformation of the system was the elimination of the Health Insurance Inspectorate in 2011. The tasks of this body were based on a pro-market approach therefore the paradigm shift was indicated by the liquidation of this organ. The county agencies of the funding body National Health Insurance Fund - and county and district agencies of the body responsible for public health and health inspection - National Public Health and Medical Officer Service - was integrated into the new general county level agency of the central government, into the County Government Office. This integration indicated the centralization trends of the health reforms as well.

From 2010/11 the Bismarckian approach of the funding has been partially changing. Although the access to the services have been based on insurance entitlement, the majority of the sources have been ensured by the tax revenues of the budget because the former employer's health insurance contribution was replaced by a tax, by the social contribution tax and the former independency of the Health Insurance was abolished and this Fund became a relatively integrant element of the budget of the central government.

The major transformation was the modification of the maintenance of the health care providers. The former local government centred approach has been replaced by a central government centred model. The reform had three steps: firstly the county hospitals were nationalized, secondly the town hospitals became state hospitals and thirdly those local hospitals which were maintained by private entities and the maintenance rights were based on concession contracts became state hospitals as well.

Thus the local self-governments (and their inter-municipal associations) are responsible now only for the basic health care and for the outpatient care institutes which are not integrated into hospitals.

The centralization of the system is very strong. In the new system the National Health Insurance Fund is responsible for financing the system, the National Public Health and Medical Officer Service is responsible for the inspection of the providers and for the protection of the patient's rights, the National Institute for Quality- and Organizational Development in Healthcare and Medicines are responsible for the maintenance of the state hospitals (except the university clinics) and for the coordination of the development of the hospitals. These three bodies are directed by the Ministry of Human Resources (for the direction of the health system has been appointed a state secretary). The former distribution of the service management tasks - which was the main element of the pro-market, pro-competition approach (Horváth, 2005, pp. 117-120) - has been discontinued. Thus in the last four years, one of the most centralized European health care systems has evolved in Hungary. 
The private providers are not excluded from the health care system although their financing is disadvantageous, because the public institutes have had tax exemptions and tax relief compared to the private providers (Tóth, 2008, p. 28). The costs of health care public services can be financed by the National Health Insurance Fund. Private insurers mainly purchase above-standard hospital services and services of non-contracted providers (mainly outpatient services) (Földes, 2014, p. 214). Thus the Hungarian system is a centralised and public law governed one and the competition is not contributed by the Hungarian legislation. Therefore the minimum standards of the EU law are harmonised, but the limited pro-market approach of the EU very limitedly prevails in the national legislation. Obviously the public administration and the centralised management are preferred. The private providers have only an additional role and the former public institutions which were transferred into publicly owned companies became public institutes after 2013 (Földes, 2014, pp. 215-217).

The rules on competition have a minor significance in the Hungarian juridical practice (Sárközy, 2001, pp. 52-55). Because of the dominant role of the public providers and insurers the decisions of the Curia (the Hungarian Supreme Court) are about the competition between the manufacturers of the medical equipment (see for example the judgement of the Curia No. Kfv. VI.37.162/2011/5).

The Hungarian legislation on cross-border health services are mostly harmonized by the EU law. The Hungarian acts on health insurance and health care were amended after the new provisions of the regulation 883/2004/ EC. The Act LXIII of 1997 was amended by the Act CXXVII of 2013 which amendment tried to implement the rules of the Directive 2011/24/EU. Thus the minimum standards of the common European health care system are mostly prevailed in Hungary (Panurjasz, 2014, pp. 68-69).

Although the system is strongly centralised and the rules of the legislative acts do not enhance the competition between the providers, this level of centralisation may be justified by the "public interest" and "public health" exceptions of the EU law.

\subsubsection{The challenges of the Directive 2011/24/EU}

The limited impact of the new rules of the Directive 2011/24/EU on the provision of health care services can be observed in Hungary where the above mentioned problems (linguistic differences etc.) are very significant. Thus the foreign trade (export and import) of the government services which includes the import of the health services has a relatively little importance which is shown by the following table. 
Table 2: Foreign trade of government services from January 2012 to September 2013 (current prices in million HUF)

\begin{tabular}{|c|c|r|r|r|}
\hline \multirow{2}{*}{ Quarter } & \multicolumn{2}{|c|}{ Import of services } & \multicolumn{2}{c|}{ Export of services } \\
\cline { 2 - 5 } & Total & $\begin{array}{r}\text { Government } \\
\text { services }\end{array}$ & Total & $\begin{array}{r}\text { Government } \\
\text { services }\end{array}$ \\
\hline 2012. Q1 & 817184 & 11868 & 1047578 & 5237 \\
\hline 2012. Q2 & 862063 & 10918 & 1157723 & 7386 \\
\hline 2012. Q3 & 897648 & 10793 & 1255553 & 6792 \\
\hline 2012. Q4 & 918962 & 11593 & 1136508 & 6789 \\
\hline 2013. Q1 & 799092 & 10832 & 1069312 & 6237 \\
\hline 2013. Q2 & 880927 & 10425 & 1191413 & 8166 \\
\hline 2013. Q3 & 936395 & 11160 & 1280568 & 6710 \\
\hline
\end{tabular}

Source: Központi Statisztikai Hivatal ${ }^{16}$.

Following the entry into force of the Directive 2011/24/EU the number of the cross-border health services has been increased, especially in the Eastern Hungarian counties. Mainly the orthopaedic and partly the gynaecological treatments are provided for foreigners especially for Romanian citizens. The Hungarian services have good quality and the language difficulties have less significance and the Hungarian hospitals are close to the border and close to the Western Romanian large municipalities (Kovács, Szócska \& Knai, 2014, pp. 333-335).

The export of the privately paid health care services - especially the major dental procedures - has a greater significance in Hungary. In 2007 the incomes from the dental services for foreigners in private providers were between 32-52 billion HUF (ca. 130-200 million EUR) (Kincses, 2010, p. 6). These services are mainly co-paid by the social insurance agencies of the EU Member States and the prices are relatively low in Hungary (Fazekas \& Koncz, 2013, pp. 53-54). ${ }^{17}$

The EU law on cross-border health care services and the coordination of the social security systems prevails. As mentioned above the EU competition law has a limited scope in the field of the health policy and the public health exception can be widely applied, thus the centralization of the health care services can be in harmony with the EU legislation. The relatively limited influence of the EU legislation on the national policies in the field of the solidarity type public services is highlighted by Márton Varju as well as by whom the national freedom of the provision of these public services - secured by the exceptions of the EU law - is highlighted (Varju, 2013, p. 119; Varju, 2014, pp. 172-173).

16 Retrieved from http://www.ksh.hu/apps/shop.kiadvany?p_kiadvany_id=16761\&p_temakor_ kod=KSH\&p_session_id=215734252791128\&p_lang=HU

17 This export is just partly realized among the export of government services: the revenues are mainly realized as revenues of tourism and transport. 
National Interest and European Law in the Legislation and Juridical Practice on Health Care Services - In the Light of the Reforms of the Hungarian Health Care System

\section{Closing Remarks and Discussion}

The influence of the EU legislation on the national health policies and the role of the national interest - in the light of the recent Hungarian reforms on the health legislation - were reviewed by this article. The approach of the analysis was jurisprudential and comparative. Main elements of the EU law by which the health legislation could be impacted were analysed. The review of the EU rules was followed by the analysis of the recent Hungarian legislative and management reforms on health care.

Thus the priority of the national interest is secured by the rules of the TFEU, the Charter of Fundamental Rights of the European Union and by the secondary law as well. Although several market-type and pro-competitive solutions have appeared, they can have only a limited influence on the national systems. The main reasons of the limited influence of the EU regulations are the primary responsibilities of the Member States, the widely applicable public health exceptions, and the limited application of the EU competition rules.

Although the national legislation is the determinative, the EU regulations on the free movement of persons and services could be applied in the field of the health care services. This principle was recognized by the landmark decisions of the European Court of Justice (ECJ). The Directive 2011/24/EU is based on these principles and a limited competition has evolved. Because the competition is limited and the creation of a single European health care area has just begun, the "silent revolution" of the public service provision has a minor importance.

The strong centralization of the Hungarian health system from 2011 to 2013 may be in harmony with the EU legislation because broad regulatory and service provision competences of the Member States are allowed by the Union in the field of health policy. The law of the European Union provides a great freedom to the national legislations. The TFEU declares that the management and provision of these services are primarily defined by the Member States. The application of the EU law is limited by 'public interest' and the 'public health' exceptions as well. The minimum standards are defined by the regulations and decisions of the EU. If the national law is in harmony with these minimum standards a centralised health care system may be in harmony with the pro-market rules of the EU.

Thus the regulatory limitations of the EU policies and legislation on health care could be shown by the Hungarian reforms. The EU approach is mainly pro-market and the competition is enhanced by the EU legislation but the new Hungarian regulation - which is strongly centralised, public law centred and with strongly limited competition - may be in accordance with the EU legislation because the minimum standards - the patient movement and the coordination of the social security systems - are secured by the Hungarian law. 
István Hoffman

István Hoffman, PhD., dr. habil. is Associate Professor of the Department of Administrative Law at the Faculty of Law of the Eötvös Loránd University in Budapest, Hungary. He was appointed to Assistant Professor in 2009 and to Associate Professor in 2014 of the Eötvös Loránd University. His current research focuses on the management and regulation of local public services (especially on welfare services) and on comparative municipal law. Dr. Hoffman is also interested in social and disability law. From 2004 to 2010 he worked for the ministries responsible for social affairs in Hungary as adviser for social and disability regulation issues. From 2009 to 2011 he was Associate Professor of Business Law at the College for Modern Business Studies in Tatabánya, Hungary. 
National Interest and European Law in the Legislation and Juridical Practice on Health Care Services - In the Light of the Reforms of the Hungarian Health Care System

\section{References}

Bekkedal, T. (2011). Article 106 TFEU Is Dead. Long Live Article 106 TFEU!. In E. Szyszczak, J. Davies, M. Andenæs \& T. Bekkedal (Eds.), Developments in Services General Interest (pp. 61-102). The Hague: T.M.C. Asser Press. DOI: $10.1007 / 978-90-6704-734-0 \_4$

Carter, C. A. (2002). Debates on Social Policy. In J. Gower (Ed.), The European Union. Handbook (pp. 185-203). Abingdon (UK) - New York (NY): Routledge.

Clasen, J. (2007). Comparative Social Policy and the European Union. In J. Baldock, N. Manning \& S. Vickerstaff (Eds.), Social Policy (pp. 601-626). Oxford: Oxford University Press.

Clasen, J. (2011). Comparative Social Policy and the European Union. In J. Baldock, N. Manning \& S. Vickerstaff (Eds.), Social Policy (pp. 396-416). Oxford: Oxford University Press.

Craig, P., \& de Búrca, G. (2003). EU Law. Text, Cases and Materials. Oxford: Oxford University Press.

Craig, P. \& de Búrca, G. (2011). EU Law. Text, Cases and Materials (5th ed.). Oxford: Oxford University Press. DOI: 10.1093/he/9780199576999.001.0001

Dawson, M. (2011). New Governance and the Transformation of European Law. Cambridge: Cambridge University Press. DOI: 10.1017/CBO9781139017442

den Exeter, A. P. (2002). Health Care Law-making in Central and Eastern Europe. Review of a Legal-Theoretical Model. Antwerp - Oxford - New York: Intersentia.

de Vries, S. A. (2011). BUPA; a Healthy Case, in the Light of a Changing Constitutional Setting in Europe?. In J. W. van de Gronden, E. Szyszczak, U. Neergard \& M. Krajewski (Eds.), Health Care and EU Law (pp. 295-316). The Hague: T.M.C. Asser Press. DOI: 10.1007/978-90-6704-728-9 12

Fabio, M. (2010): Customs Law of the European Union. Alphen aan den Rijn: Kluwer Law International.

Fazekas M., \& Koncz, J. (2013). Egészségügyi jog és igazgatás. In A. Lapsánszky (Ed.), Közigazgatási jog. Fejezetek szakigazgatásaink köréből. III. kötet Humán közszolgáltatások igazgatása (pp. 17-82). Budapest: Complex.

Földes, M. É. (2014). Addressing Equality in Health Care at the Public-Private Intersection: The Role of Health Rights Enforcement in Hungary. In: C. M. Flood \& A. Gross (Eds.), The Right to Health at the Public/Private Divide. A Global Comparative Study (pp. 208-235). Cambridge: Cambridge University Press. DOI: $10.1017 /$ CBO9781139814768.011

Greber, P.-Y., Rilliet Howald, A., \& Kahil-Wolff, B. (2001). Who Gets What? New Policies Relating Access and Adequacy of Health Care. In D. D. Hoskins, D. Dobbernack \& Ch. Kuptsch (Eds.), Social Security at the Down of the $21^{\text {st }}$ Century (pp. 231-269). New Brunswick (NJ): Transaction Publishers.

Hatzopoulos, V., \& Stergiou, H. (2011). Public Procurement Law and Heaéth Care: From Theory to Practice. In J. W. van de Gronden, E. Szyszczak, U. Neergard \& M. Krajewski (Eds.), Health Care and EU Law (pp. 413-452). The Hague: T.M.C. Asser Press. DOI: 10.1007/978-90-6704-728-9_17

Hervey, T. K., \& McHale, J. V. (2004). Health Law and the European Union. Cambridge: Cambridge University Press. DOI: 10.1017/CBO9780511617553 
Hervey, T. K. (2011). If Only It Were So Simple: Public Law Services and EU Law. In M. Cremona (Ed.), Market Integration and Public Services in the European Union (pp. 179-250). Oxford: Oxford University Press.

DOI: 10.1093/acprof:oso/9780199607730.003.0007

Hoffman, I. (2013). Some Thoughts on the Main European Models of the Municipal Health Services. Lex localis, 11(3), 631-650.

Horváth, M. T. (2005). Közmenedzsment. Budapest - Pécs: Dialóg-Campus.

Horváth, M. T. (2013). Csendes fordulat. Jogtudományi Közlöny, 67(4), 173-182.

Kaczorowska, A. (2013). European Union Law. Abingdon (UK) - New York (NY): Routledge.

Kincses, G. (2010). Az egészségügyi turizmus helyzete, jövôképe, szükséges fejlesztési irányai. IME - az egészségügyi vezetök szaklapja, 9(6), 5-12.

Koivusalo, M. (2013). We are all in this together - European policies and health systems change. In P. Wilson (Ed.), Health Care Reform and Globalisation. The US, China and Europe in Comparative Perspective (pp. 93-117). Abingdon (UK) New York (NY): Routledge.

Kovács, E., Szócska, G., \& Knai, C. (2014). International Patients on Operation Vacation - Perspectives of Patients Travelling to Hungary for Orthopaedic Treatments. Health Policy and Management, 3(6), 333-340.

DOI: $10.15171 /$ ijhpm.2014.113

Lamping, W. (2013): European Union Health Care Policy. In S. L. Greer \& P. Kurzer (Eds.), European Union Public Health Policy: Regional and global trends (pp. 19-35). Abingdon (UK) - New York (NY): Routledge.

Legido-Quigley, H., McKee, M., Nolte, E., \& Glinos, I. A. (2008). Assuring the Quality of Health Care in the European Union. Copenhagen: WHO Regional Office for Europe.

Meyer, H. J. (2013). Current Legislation on Cross-Border Health Care in European Union. In I. G. Cohen (Ed.), The Globalization and Health Care. Legal and Ethical Issues (pp. 83-103). Oxford: Oxford University Press. DOI: 10.1093/acprof:oso/9780199917907.003.0005

Moens, G., \& Trone, J. (2010). Commercial Law of the European Union. Dordrecht: Springer. DOI: $10.1007 / 978-90-481-8774-4$

Nistor, L. (2011). Public Services and the European Union. Healthcare, Health Insurance and Education Services. The Hague: T.M.C. Asser Press. DOI: $10.1007 / 978-90-6704-805-7$

Panurjasz, A. A. (2014). A határon átnyúló egészségügyi ellátásra vonatkozó betegjogok érvényesítéséről szóló irányelv. Európai Tükör, 19(2), 67-71.

Peeters, M. (2012). Free Movement of Patients: Directive 2011/24 on the Application of Patient's Rights in Cross-Border Healthcare. European Journal of Health Law, 19(1), 29-60. doi: 10.1163/157180912X615158

Sárközy, T. (Ed.). (2008). Versenyjog. Budapest: HVG-Orac.

Tóth I. (2008). A nem költségvetési formában mûködô egészségügyi intézmények finanszírozási hátrányai. IME - az egészségügyi vezetök szaklapja, 7(7), 24-28.

van den Gronden, J. W. (2011). Social Services of General Interest and EU Law. In E. Szyszczak, J. Davies, M. Andenæs \& T. Bekkedal (Eds.), Developments in Services of General Interest (pp. 123-154). The Hague: T.M.C. Asser Press. DOI: 10.1007/978-90-6704-734-0_6 
National Interest and European Law in the Legislation and Juridical Practice on Health Care Services - In the Light of the Reforms of the Hungarian Health Care System

Varju, M. (2013). A közszolgáltatások szabályozása az Európai Unióban. In M. T. Horváth (Ed.), Kilengések. Közszolgáltatási változások (pp. 103-138). Budapest - Pécs: Dialóg-Campus.

Varju, M. (2014). A közszolgáltatási piacon történő állami szerepvállalás keretei az Európai Unió jogában. In M. T. Horváth (Ed.), Külön utak. Közfeladatok megoldásai (pp. 161-184). Budapest - Pécs: Dialóg-Campus.

Waltermann, R. (2011). Sozialrecht. Heidelberg: C. F. Müller. 
POVZETEK

1.02 Pregledni znanstveni članek

\section{Nacionalni interes in evropsko pravo v zakonodajni in pravni praksi zdravstvene dejavnosti - z vidika reform madžarskega sistema zdravstvenega varstva ${ }^{1}$}

Ključne besede: zdravstveno varstvo, harmonizacija, vpliv EU na nacionalno zdravstveno politiko, nacionalne zdravstvene politike, Madžarska

Članek se v luči nedavnih madžarskih reform na področju zdravstvene zakonodaje osredotoča na vpliv zakonodaje Evropske unije na nacionalne zdravstvene politike in na vlogo nacionalnega interesa. Pristop k analizi je bil jurisdiktičen in primerjalen. Članek analizira elemente prava Evropske unije, ki bi lahko vplivali na nacionalno zdravstveno zakonodajo. Pregledu pravil Evropske unije sledi še analiza nedavne madžarske zakonodaje in upravljanja reform na področju zdravstva.

Vpliv Evropske unije na področju socialne politike je že tradicionalno šibek, vendar je zdravstveno varstvo treba obravnavati kot izjemno specifičen sektor. Evropsko sodišče namreč več storitev zdravstvenega varstva obravnava kot storitve, ki so vsaj delno v skladu z Uredbo o prostem pretoku storitev. Vendar pa je zaščita zdravja in življenja ljudi dopustna oz. sprejemljiva izjema t. i. »štirih temeljnih svoboščin«. Dostop do storitev zdravstvenega varstva za prebivalce Evropske unije v drugih državah članicah velja za instrument prostega gibanja oseb. Tako se je zagotavljanje storitev zdravstvenega varstva znašlo na razpotju nacionalne in Evropske uredbe, medtem ko vpliv evropske politike velja za pomemben in pogosto obravnavan element.

Obseg javnozdravstvene politike $v$ Evropski uniji je omejen, nacionalne pristojnosti, kot del socialne politike $v$ širšem smislu, pa so odločilne. Opredelitev strukture in financiranja nacionalnega zdravstvenega sistema ter opredelitev sredstev za dostop sta del odgovornosti nacionalne zakonodaje, v zveznih državah včasih tudi del podnacionalne (članice zveze) zakonodaje. Ti sistemi se na prvi pogled razlikujejo.

Prosto gibanje oseb je sprožilo koordinacijo socialnih politik, in kot del tega procesa, tudi koordinacijo dostopa do zdravstvenega varstva. Evropsko sodišče je storitve zdravstvenega varstva od konca 1980-ih let opredelilo kot storitve, ki so predmet predpisov o prostem pretoku storitev (glej primera Poucet/Pistre ali primer Watts). Konvergenčni okvir nacionalnih sistemov je bil razvit z odprto metodo koordinacije, ki jo je institucionalizirala Amsterdamska

1 Ta študija temelji na raziskavah raziskovalne skupine pri Madžarski akademiji znanosti in Univerze v Debrecenu (MTA-DE) o Uredbah lokalnih javnih služb (2012-2016). 
National Interest and European Law in the Legislation and Juridical Practice on Health Care Services - In the Light of the Reforms of the Hungarian Health Care System

pogodba. Zato je konvergenco mogoče upoštevati pri storitvah zdravstvenega varstva, čeprav so "preživele« tudi številne razne administrativne in finančne storitve.

Pomembne razlike je tako mogoče zaznati zlasti med državami z decentraliziranimi modeli zdravstvenega varstva in državami s centraliziranimi modeli zdravstvenega varstva. Pri decentraliziranih modelih so lokalne skupnosti odgovorne za organizacijo večine storitev splošnega zdravstvenega varstva, pri čemer samoupravne enote na ravni naselja organizirajo osnovne (primarne) zdravstvene storitve, medtem ko lokalni vladni organi na vmesni stopnji organizirajo ambulantno in bolnišnično nego. Decentralizirani model je v Evropi tipičen, a ne tudi splošno privzet: osrednji vladni organi so široko odgovorni za zagotavljanje zdravstvenih storitev v več državah. Prav nasprotno pa pri centraliziranem modelu lokalni vladni organi niso odgovorni za zdravstvene storitve oziroma so za njih odgovorni le v manjšem obsegu.

Čeprav je način za dostop do varstva različen po vsej Evropi (v skladu z nacionalnimi pristojnostmi glede sistemov socialne varnosti), pa odločilna večina Evropskega prebivalstva lahko uporablja storitve zdravstvenega varstva. To je mogoče interpretirati kot praktično konvergenco, ki ima pomemben vpliv na nacionalne sisteme financiranja.

Evropska uredba je bila nekoliko razširjena tudi na tem področju. Uporabo pacientovih pravic v čezmejnem zdravstvenem varstvu ureja Direktiva 2011/24/EU, ki je razširila zagotovitev čezmejnih storitev, obenem pa je nanjo mogoče gledati kot na »katalizatorja« čezmejne konkurenčnosti in konvergence sistemov.

Ta sprememba nakazuje, da je konkurenčnost med (nacionalnimi) ponudniki pomemben element evropske politike. Konkurenčno pravo velja za pomemben element konvergence storitev zdravstvene nege - primeri Evropskega sodišča so bili deloma primeri o upoštevanju proste konkurence.

Čeprav se je konvergenca teh sistemov povečala, so nacionalni sistemi ostali. Nacionalni interes priznava tudi Evropska unija. Prvič, omejeni obseg evropske socialne politike in drugič, izjema o zaščiti zdravja in življenja ljudi kažeta na dejstvo, da je zgolj okvir skupne evropske politike institucionaliziran s pogodbami. Nacionalne zakonodaje imajo namreč močne pristojnosti in kot take lahko služijo glavnim elementom nacionalnih sistemov. Zato je nacionalni interes (zaščita zdravja) močan omejitveni dejavnik skupne evropske politike.

Čeprav so bili instrumenti za zagotavljanje storitev, ki jih ureja javno pravo, v zadnjih nekaj desetletjih močno okrepljeni v evropski uredbi in v praksi Evropskega sodišča, pa je paradigma, ki temelji na širjenju konkurenčnosti na področju zdravstvenega varstva, še vedno prisotna. Ta pojav ima namreč več izvorov. Konkurenca je bila na področju zdravstvenega varstva omejena, medtem ko imajo po drugi strani odločilno vlogo (nacionalni) akterji, ki jih ureja javno pravo. 
Z analizo sprememb madžarskega sistema zdravstvenega varstva je bilo mogoče ugotoviti »razpotje« ali »dvoličnost« zdravstvenega varstva med močnim nacionalnim interesom in vse bolj obsežno čezmejno konkurenčnostjo. Med komunističnim obdobjem je na Madžarskem bilo še več elementov nekdanjega Bismarckovega sistema, zato je bil proces rekonstrukcije modela socialnega zavarovanja hiter. Novi sistem zdravstvenega varstva je temeljil na upravljavski paradigmi, medtem ko so bile odgovornosti za zagotavljanje storitev močno deljene. Ta sistem se je v zadnjih nekaj letih spremenil: novi madžarski sistem zdravstvenega varstva je močno centraliziran in upravljan večinoma z instrumenti javnega prava. $V$ zaključnem delu članka je analiza te spremembe in njene skladnosti s pravom Evropske unije.

Močna centralizacija madžarskega zdravstvenega sistema od leta 2011 do leta 2013 je morda v skladu z zakonodajo Evropske unije, saj Unija na področju zdravstvene politike dovoljuje široke regulativne pristojnosti in pristojnosti zagotavljanja zdravstvenih storitev držav članic. Pravo Evropske unije omogoča veliko svobode nacionalnim zakonodajam. Iz Pogodbe o delovanju Evropske unije (PDEU) namreč izhaja, da je upravljanje in zagotavljanje zdravstvenih storitev primarno določeno v zakonodaji držav članic. Uporabo prava Evropske unije omejujejo tudi »javni interes« in izjeme »javnega zdravja«. Minimalni standardi so opredeljeni z uredbami in odločitvami Evropske unije. Če je nacionalno pravo v skladu z omenjenimi minimalnimi standardi, je najverjetneje centralizirani sistem zdravstvenega varstva v skladu s tržno usmerjenimi pravili Evropske unije.

Regulativne omejitve politik in zakonodaje Evropske unije glede zdravstvenega varstva bi bilo zato mogoče prikazati s primerom madžarskih reform. Pristop Evropske unije je večinoma tržno usmerjen, konkurenčnost pa je podkrepljena z zakonodajo Evropske unije. A nova madžarska uredba (ki je močno centralizirana, ima osredotočeno javno pravo in močno omejeno konkurenčnost) je morda v skladu z zakonodajo Evropske unije, saj so z madžarskim pravom zagotovljeni tudi minimalni standardi (gibanje pacientov in koordinacija sistemov socialnega varstva). 